\title{
Determination of Curie Point Depth, Heat Flow and Geothermal Gradient from High Resolution Aeromagnetic Data around Lamurde Area, Adamawa State, North-Eastern Nigeria
}

\author{
S. Kasidi \\ Department of Geology, Adamawa State University, Mubi, Nigeria \\ Email: kasidisimon2002@yahoo.co.uk
}

How to cite this paper: Kasidi, S. (2019) Determination of Curie Point Depth, Heat Flow and Geothermal Gradient from High Resolution Aeromagnetic Data around Lamurde Area, Adamawa State, North-Eastern Nigeria. Open Journal of Geology, 9, 829-838. https://doi.org/10.4236/ojg.2019.911093

Received: August 5, 2019

Accepted: October 19, 2019

Published: October 22, 2019

Copyright $\odot 2019$ by author(s) and Scientific Research Publishing Inc. This work is licensed under the Creative Commons Attribution International License (CC BY 4.0).

http://creativecommons.org/licenses/by/4.0/

\section{(c) (i) Open Access}

\begin{abstract}
Analysis of high resolution of aeromagnetic data was carried out over Lamurde, Adamawa state north-eastern Nigeria to determine the Curie point depth (CPD), heat flow and geothermal gradient. The aeromagnetic data used for this work was obtained at Nigerian geological survey agency, the total magnetic intensity was processed to produce the residual magnetic map which was divided into 4 overlapping blocks, each block was subjected to spectral analyses to obtain depths to the top boundary and centroid, while depth to bottom of the magnetic sources was calculated using empirical formula. The depths values obtained were then used to assess the CPD, heat flow and geothermal gradient in the area. The result shows that the CPD varies between 9.62 and $10.92 \mathrm{~km}$ with an average of $10.45 \mathrm{k}$, the heat flow varies between 150.73 and $132.78 \mathrm{mWm}^{-20} .{ }^{\circ} \mathrm{C}^{-1}$ with an average of $139.12 \mathrm{mWm}^{-20} .{ }^{\circ} \mathrm{C}^{-1}$ and the geothermal gradient in the study area varies between 12.16 and $15.67{ }^{\circ} \mathrm{C} / \mathrm{km}$ with an average of $13.39{ }^{\circ} \mathrm{C} / \mathrm{km}$. In view of the above results, the high heat flow may be responsible for maturation of hydrocarbon in Benue Trough as well as responsible for the lead Zinc Mineralization. Again by implication, Lamurde area can be a good area for geothermal reservoir exploration for an alternative source for power generation.
\end{abstract}

\section{Keywords}

Adamawa State, Curie Depth, Maturation of Hydrocarbon, Geothermal Gradient, Heat Flow and Alternative Power Generation

\section{Introduction}

The study area lies in the upper Benue Trough between latitude $9^{\circ} 00 \mathrm{~N}$ and $9^{\circ} 3^{\prime} \mathrm{N}$ 
and longitude $11^{\circ} 00 \mathrm{E}$ and $12^{\circ} 00^{\prime} \mathrm{E}$ (Figure 1). It is one of the areas that received limited attention from geoscientists in the past.

This research work aimed at estimation of Curie Point Depth (CPD), heat flow and geothermal gradient in Lamurde and Environs, North-Eastern Nigeria, by analysis of high resolution aeromagnetic data. One of the tools used in investigating thermal structure of crust via aeromagnetic studies is spectral analysis. Several studies have shown that magnetic data can be used to determine the thermal structure of the earth's crust in various geologic environments [1] [2] [3], for example, dominant magnetic minerals in the earth crust change from being ferromagnetic to paramagnetic at a temperature known as Curie Point Temperature (CPT). Magnetite $\left(\mathrm{FeZO}_{4}\right)$ is the most common magnetic materials in igneous rocks and has an approximate $\mathrm{CPT}$ of $580^{\circ} \mathrm{C}$ [4]. At temperature above $\mathrm{CPT}$, the thermal agitation of the ferromagnetic rock material leads to the spontaneous alignment of the different domains in the minerals and becomes randomized to the point that ferromagnetic minerals become totally paramagnetic [5].

The surface lineaments around the study area and their influence on the hot springs manifestations have not been previously investigated. The depth to the

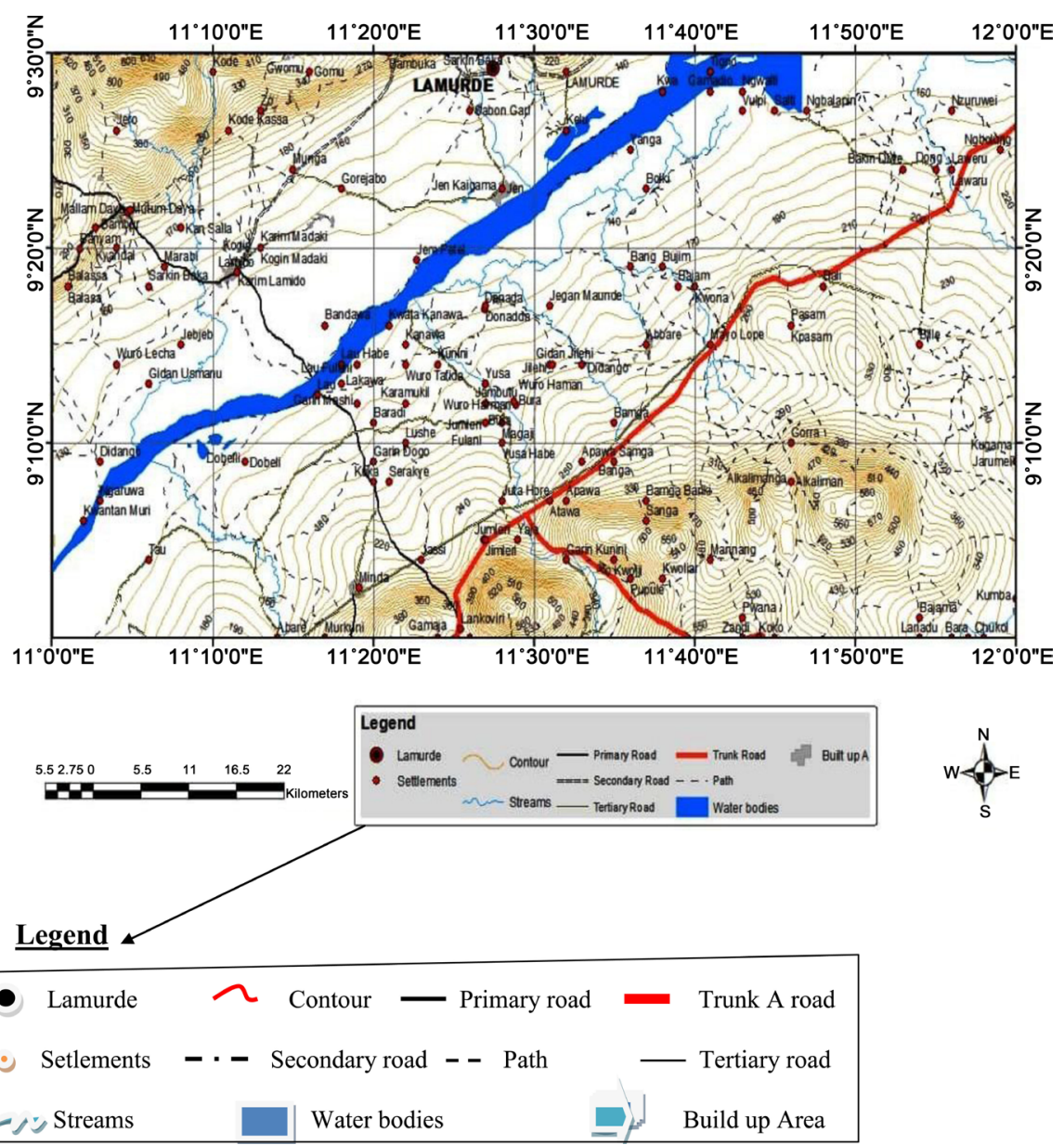

Figure 1. Location/topographic map of the study area [10]. 
heat sources which could provide information on the thermal structure has not been investigated either. In this research, the thermal structure around Lamurde and Environs, North-Eastern Nigeria was investigated in order to explore the geothermal potential using aeromagnetic data.

Thermal structure of the crust involving Curie depth isotherm estimations has been published for various tectonic settings (e.g. [6] [7] [8]).

Studies of Curie Point Depth (CPD) in some other parts of the world especially African-Eurasian convergence zone, SW Turkey by [9] estimated the Curie Point Depth variations and used it to examined the thermal structure of the crust which is of great significance. From these estimates, comparisons were made for the thermal state of the crust with the seismic activity to provide insights for spatial limits of brittle failure in a region. This is because thermal structure of the crust determines modes of deformation, depths of brittle and ductile deformation zones, regional heat flow variations, seismicity, subsidence/uplift patterns and maturity of organic matter in sedimentary basins. Based on finding of the above authors, the deeper curie depth is associated with low heat flow while the shallow Curie depth is associated with high heat flow and high geothermal potentials.

\section{Geology of the Study Area}

The geology of the area is made up of Precambrian basement complex rocks which are believed to be mainly of gneiss-migmatites complex remnants of meta-sediments and older granite. Deformation described as Augen gneisses due to their eye shaped structure.

The older granites of Nigeria are calc-alkaline in chemical composition. These are also granite rock seen to have intrude the basement complex. Analysis have shown that, older granite are muscovite, granite, biotite granite aplite, quartz diorite etc. they show weak alignment of constituent platy minerals which a times result to their weak foliation.

The Cretaceous sedimentary rocks, which include rocks of Dukul, Yolde and Bima sandstone formation [11], describe the Benue Trough was in details and suggests that the Cretaceous sediment belongs to the oldest sedimentary Bima Sandstone whose lower beds are more feldspathic than the higher beds. The Bima Sandstone which overlies the basement complex at the base of sedimentary succession was derived from granitic rocks [12]. The lower beds of the formation are invariably series of calcareous sandstone and shale which marks the transition from continental to marine shale with a number of limestone beds towards the base of the formation, known as Yolde Formation.

The Tertiary-Recent volcanic rocks in the study area consist of the basalts, trachyte, rhyolite, and newer basalts of eastern arm of Cameroon volcanic line. [13] discussed the events of volcanisms in the Benue Valley, and the Adamawa basement, which was compared with that of the Cameroon volcanic line. In this area the volcanic rocks are dominantly basalts. 
Stratigraphically, the basement complex rocks are the oldest and the Quaternary alluvium deposit being the youngest which formed mainly from the weathered rocks dominating the study area (Figure 2).

\section{Materials and Methods}

The data for this study is a high resolution aeromagnetic data obtained from $\mathrm{Ni}$ geria geological survey Agency [15]. The total magnetic intensity data was processed to produce residual magnetic map. This data was divided into overlapping blocks to carry out spectral analysis, which was then used to obtain the depths to top boundary and Centroid. Steps for determining depth to top bound and centroid has been discussed extensively by several authors [16] [17] [18] [19].

The analysis was done using computer software (Oasis Montaj) and Mat lab designed for analysis of potential field data. In this research, the spectral analysis was made using interactive Oasis Montaj, Version 8.2 which enables two dimensional frequency domains processing of potential field data. The results of the analysis are plotted on a logarithmic scale against the radial wave number using a simple programme in Mat lab. On such a plot, if a group of sources has the same depth, they will fall onto a line of constant slope (tangent of the line fitted to the power spectra). Thus, if there are sources at different depths, such as a shallow plutonic formation over a deep basement, the plot will be separate into two or more sections with different slope. The reciprocal of the angle of slope is a measure of the depth to the source. This process was carried out to obtain the depth to the top boundary $\left(Z_{t}\right)$ and depth to the centroid $\left(Z_{0}\right)$ for the four overlapping blocks (Figure 3).

To carry out the analysis, the initial step according to [6] was followed to estimate the depth to the centroid $\left(Z_{0}\right)$ of the magnetic sources from the slope of

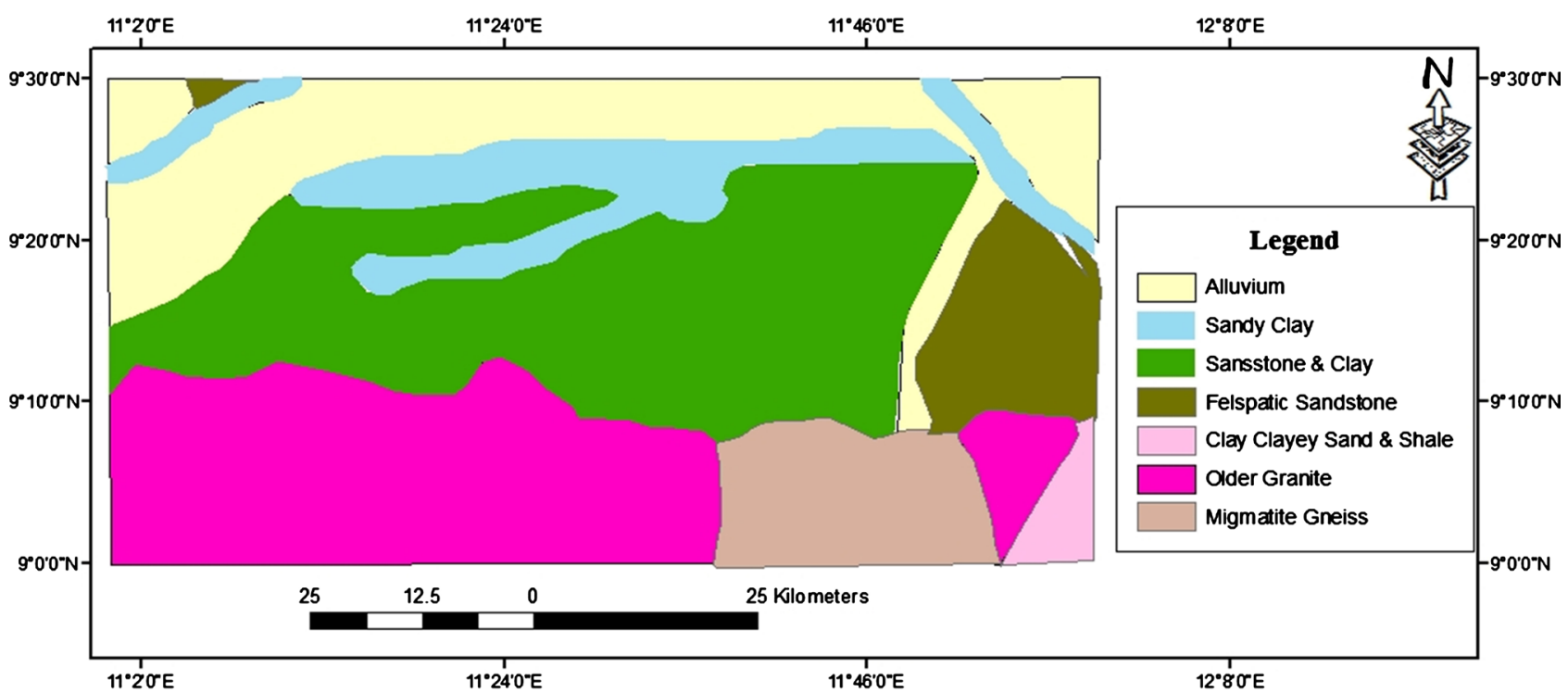

Figure 2. Geologic map of the study area (after [14]). 
the longest wave length of the spectrum as given:

$$
\log \left(P \frac{(K)^{\frac{1}{2}}}{/ K /}\right)=\log (A)-2 \pi Z_{0} / K /
$$

where $P(K)$ is the radially averaged power spectrum of the anomaly $/ K /$ is the spatial wave number and $A$ is a constant.

The second step was to estimation of the depth to the top boundary $\left(Z_{t}\right)$ of the magnetic source from the slope of the line with the second wave length.

$$
\log \left(P(K)^{\frac{1}{2}}\right)=\log (B)-2 \pi Z_{t} / K /
$$

where, $B$ is a sum of constants independent of $/ K /$. The basal depth $\left(Z_{b}\right)$ of the magnetic source is then computed from the equation:

$$
Z_{b}=2 Z_{0}-Z_{t}
$$

The obtained basal depth $\left(Z_{b}\right)$ of a magnetic source is assumed to be equal to the CPD.

Analysis of CPD is one of the methods used to estimate the temperature gradient and the heat flow in the crust. Heat flow is defined by Fourier's Law as:

$$
Q=d\left[\frac{\mathrm{d} T}{\mathrm{~d} Z}\right]
$$

where $Q$ is the heat flow and $d$ is the coefficient of thermal conductivity. In this equation, it is assumed that the direction of the temperature variation is vertical and the temperature gradient $\mathrm{d} T / \mathrm{d} Z$ is constant. Accordingly, the Curie temperature; can be obtained from the Curie Point depth $\left(Z_{b}\right)$ and the thermal gradient $\mathrm{d} T / \mathrm{d} Z$ using the following equation:

$$
\phi=Z_{b}\left[\frac{\mathrm{d} T}{\mathrm{~d} Z}\right]
$$

Equations (4) and (5) give a relationship between the $\operatorname{CPD}\left(Z_{b}\right)$ and the heat flow $(Q)$ as:

$$
Q=d\left[\frac{Q}{Z_{b}}\right]
$$

In Equation (6), the Curie point depth is inversely proportional to the heat flow. In this research, the Curie Point Temperature of $580^{\circ} \mathrm{C}$ and thermal conductivity of $2.5 \mathrm{mWm}^{-1} .{ }^{\circ} \mathrm{C}^{-1}$ as average for igneous rocks was used as Standard. In order to calculate the thermal gradient and heat flow in the study area, Equations (5) and (6) were used.

\section{Discussion of Results}

Having examined both the TMI and the residual map of the study area (Figure 3 and Figure 4), it is observed that, the study area is made up of magnetic high and magnetic low signatures. The magnetic high observed on the TMI (Figure 3) 


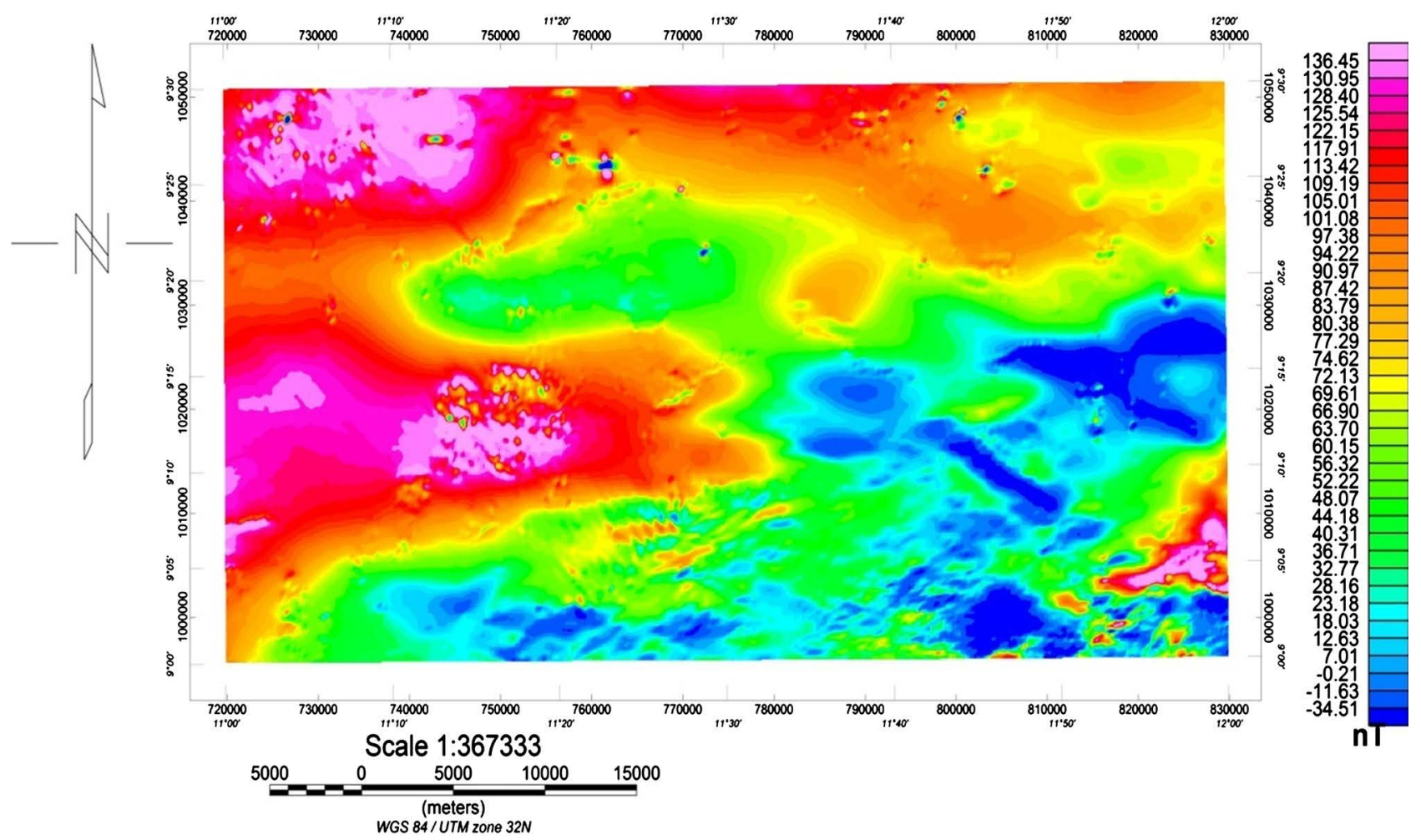

Figure 3. Total magnetic intensity map of the study area.
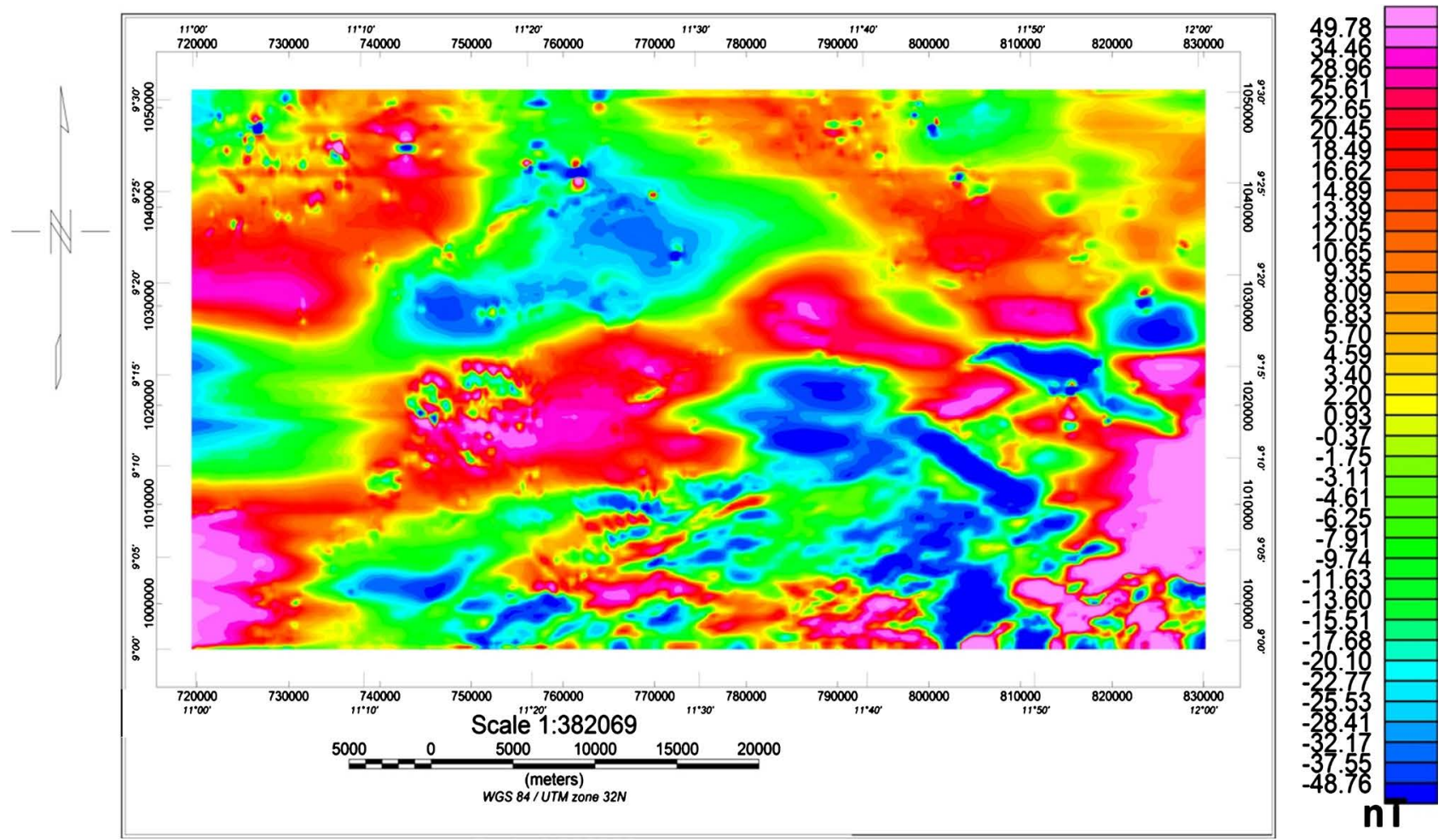

Figure 4. Residual magnetic map of the study area. 
are of magnitude 7.0 to $136.45 \mathrm{nT}$, and magnetic low observed are of magnitude -2.0 to $-34.51 \mathrm{nT}$ After regional residual separation the magnetic high observed on the residual data (Figure 4) ranges from 0.93 to $49.78 \mathrm{nT}$, and the magnetic low ranges between -0.37 to $-48.76 \mathrm{nT}$, therefore the magnetic high on both data could be as result of basic intrusive within the Upper Benue Trough while the magnetic low could be as result of thick sedimentary cover in the Benue valley. However, low magnetic area is in the south eastern part of Figure 4 while the high magnetic areas spread across the study area. This can be related to the differences in depth to top boundary and centroid in the study area as obtained.

The average power and wave number spectra for each of the four overlapping blocks were calculated and used to estimate the CDPs (Figure 5). The right-hand side of high-wave-number portion of the spectra which was used to estimate the depth to top boundary of the magnetic sources $\left(Z_{t}\right)$, while the left-hand side indicated the slope of the lower-wave-number-scaled spectra, which was also used to estimate the depth to centroid $\left(Z_{0}\right)$ of the magnetic sources.

The results from the analysis and the one obtain from empirical formula are shown on Table 1. From the table, the estimated CDP varies between 9.62 and $10.92 \mathrm{~km}$ with an average of $10.45 \mathrm{~km}$. This indicates that, the CPD varies significantly with different geologic environments [20], when the CPD results is
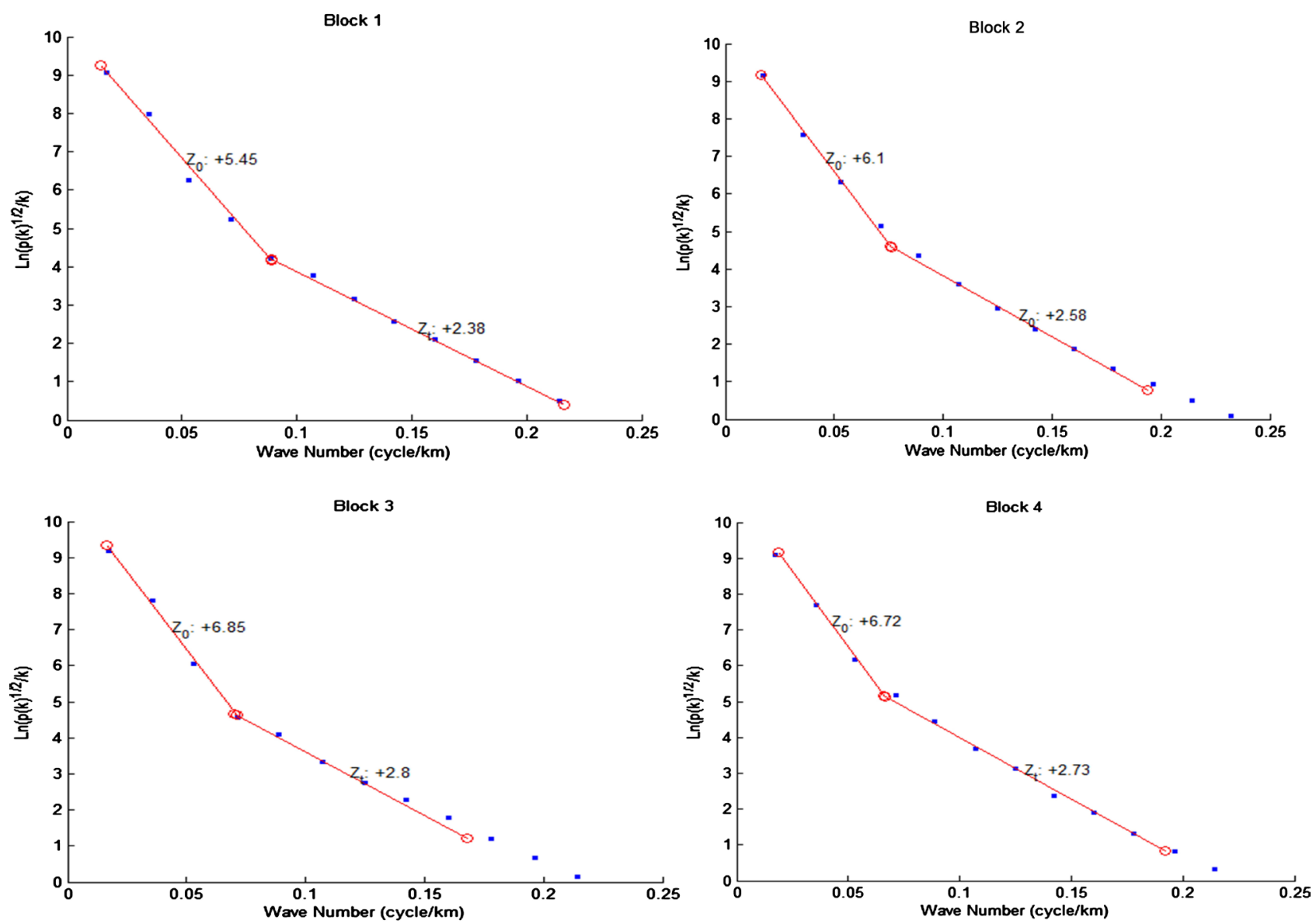

Figure 5. Graphs of the logarithms of the spectral energies for the blocks 1-4. 
Table 1. Calculated curie depth, head flow and geothermal gradient.

\begin{tabular}{cccccc}
\hline Block & $\begin{array}{c}\text { Depth to Top } \\
\text { Boundary }\left(Z_{E}\right) \text { in } \\
\mathrm{km}\end{array}$ & $\begin{array}{c}\text { Depth to } \\
\text { Centroid }\left(Z_{0}\right) \text { in } \\
\mathrm{km}\end{array}$ & $\begin{array}{c}\text { Curie Point } \\
\text { Depth }\left(Z_{b}\right) \text { in } \\
\mathrm{km}\end{array}$ & $\begin{array}{c}\text { Heat Flow in } \\
\mathrm{mWm}^{-20} .{ }^{\circ} \mathrm{C}^{-1}\end{array}$ & $\begin{array}{c}\text { Geothermal } \\
\text { Gradient }{ }^{\circ} \mathrm{C} / \mathrm{KM}\end{array}$ \\
\hline 1 & 2.38 & 6.46 & 10.54 & 137.57 & 13.10 \\
2 & 2.58 & 6.10 & 9.62 & 150.73 & 15.67 \\
3 & 2.80 & 6.86 & 10.92 & 132.78 & 12.16 \\
4 & 2.73 & 6.72 & 10.71 & 135.38 & 12.64 \\
\hline
\end{tabular}

compared with what is obtain across the world, it can be opined that volcanic, tectonic and associated geodynamic environments have CPD shallower than 10 $\mathrm{km}$, while CPDs ranging between 15 to $25 \mathrm{~km}$ are as a result of island arcs and ridges and deeper than $25 \mathrm{~km}$ in plateaus and tranches.

Similarly, the results on Table 1 from mathematical computation using empirical formula reveals that, the heat flow in the study area vary between 150.73 and $132.73 \mathrm{mWm}^{-20} .{ }^{\circ} \mathrm{C}^{-1}$ with an average of $139.12 \mathrm{mWm}^{-20} .{ }^{\circ} \mathrm{C}^{-1}$, while the geothermal gradient varies between 12.16 and $15.67{ }^{\circ} \mathrm{C} / \mathrm{km}$ with an average of $13.39{ }^{\circ} \mathrm{C} / \mathrm{km}$. Though, the region that comprises of high heat flow values correspond to volcanic and metamorphic regions since they have high thermal conductivity. With the results obtained it is evident that the study area is potential site for geothermal exploration for alternative source for power generation and in addition to that the shallow CPD and high heat flow is responsible for some hot springs in Lamurde and environs.

\section{Conclusions}

The high resolution aeromagnetic anomaly data over Lamurde and Environs, North-Eastern Nigeria have been analyzed to estimate Curie Point Depth, heat flow and geothermal gradient. The result shows that CPD varies between 9.62 and $10.92 \mathrm{~km}$ with an average of $10.45 \mathrm{~km}$, the heat flow varies between 150.73 and $132.78 \mathrm{mWm}^{-20} .{ }^{\circ} \mathrm{C}^{-1}$ with an average of $139.12 \mathrm{mWm}^{-20} .{ }^{\circ} \mathrm{C}^{-1}$ and geothermal gradient varies between 12.16 and $15.67^{\circ} \mathrm{C} / \mathrm{km}$ with an average of $13.39^{\circ} \mathrm{C} / \mathrm{km}$.

The area is observed to have shallow Curie point depth and corresponding high heat flow (above $150 \mathrm{mWm}^{-20} .{ }^{\circ} \mathrm{C}^{-1}$ ), thus, suggesting anomalous geothermal condition. Hence, further detail studies are recommended in the study area. It is known that geodynamics processes are mainly controlled by the thermal structure of the earth crust; therefore, this study is anticipated to contribute significantly to the quantitative appraisal of the CPD, heat flow and geothermal gradient in Lamurde and Environs.

\section{Acknowledgements}

The authors are grateful to the Nigerian Geological Survey Agency (NGSA) for releasing the aeromagnetic data at subsidize rate and to the Geosoft for providing Oasis Montaj software which was used for processing the data. 


\section{Conflicts of Interest}

The author declares no conflicts of interest regarding the publication of this paper.

\section{References}

[1] Blakely, R.G. and Hassan Zadeh, S. (1981) Estimation of Depth to Magnetic Source Using Maximum Entropy Power Spectra, with Application to the Peru-Chile. Trench. Memoir of the Geological Society of America, 154, 667-682. https://doi.org/10.1130/MEM154-p667

[2] Okubo, Y., Graf, J.R., Hasen, R.O., Ogawa, K. and Tsu, H. (1985) Cuire Point Depth of the Island of Kyushu and Surrounding Area, Japan. Geophysical, 53, 481-494. https://doi.org/10.1190/1.1441926

[3] Spector, A. and Grant, F.S. (1970) Statistical Model for Interpreting Aeromagnetic Data. Geophysics, 35, 293-302. https://doi.org/10.1190/1.1440092

[4] Stacey, F.O. (1977) Physics of the Earth. John Wiley and Sons, New York.

[5] Langel, R.A. and Hinze, W.J. (1998) The Magnetic Field of the Lithosphare: The Satellite Perspective. Cambridge University Press, Cambridge, UK, 157. https://doi.org/10.1017/CBO9780511629549

[6] Bhattacharyya, B.K. and Leu, L.K. (1975) Spectral Analysis of Gravity and Magnetic Anomalies Due to Two Dimensional Sources. Geophysics, 40, 993-1031. https://doi.org/10.1190/1.1440593

[7] Nwanko, L.I., Olasehinde, P.I. and Akoshile, C.O. (2011) Heat Flow Anomalies from Spectral Analysis of Airborne Magnetic Data of Nupe Basin, Nigeria. Asian Journal, Earth Science, 4, 20-28. https://doi.org/10.3923/ajes.2011.20.28

[8] Tanaka, A., Okubo, Y. and Matsubayashi, O. (1999) Curie Point Depth Base on Spectrum Analysis of the Magnetic Anomaly Data in East and South East Asia. Tectronophysics, 306, 461-470. https://doi.org/10.1016/S0040-1951(99)00072-4

[9] Nuri, D.M., Timur, U.Z., Mumtaz, H. and Naci, O. (2005) Curie Point Depth Variations to Infer Thermal Structure of the Crust at the African-Eurasian Convergence Zone, SW Turkey. Earth, Planets and Space, 57, 373-383. https://doi.org/10.1186/BF03351821

[10] USGS (2012) United State Geological Survey Data Base.

[11] Carter, J.D., Barber, W., Tait, E.A. and Jones, G.P. (1963) The Geology of Parts of Adamawa, Bauchi and Bornu Provinces in North-Eastern Nigeria. Geological Survey of Nigeria. Bulletin, 30.

[12] Offodile, M.E. (1977) A Review of the Geology of the Cretaceous of the Benue Trough in Geology of Nigeria (Ed. C.A). Elizabeth Press, Lagos, 319-330.

[13] Grant, N.K. (1978) Structural Distinction between a Metasedimentary Cover and Underlying Basement in 600-m.y-Old Pan-African Domain of Northwest Nigeria, West African. GSA Bulletin, 89, 50-58. https://doi.org/10.1130/0016-7606(1978)89<50:SDBAMC>2.0.CO;2

[14] Nigerian Geological survey Agency (2006) Geological Map of Nigeria 1:100,000.

[15] Nigerian Geological survey Agency (2010) Aeromagnetic Data of Nigeria.

[16] Abubakar, Y.I., Umego, M.N. and Ojo, S.B. (2010) Evolution of Gongola Basin Upper Benue Trough North Eastern Nigeria. Asia Journal of Earth Sciences, 3, 62-72. https://doi.org/10.3923/ajes.2010.62.72 
[17] Chinwuko, A.I., Onwuemesi, A.G., Anakwuba, E.K., Okeke, H.C., Onuba, L.N., Okonkwo, C.C. and Ikumbar, E.B. (2013) Spectral Analysis and Magnetic Modeling over Biu-Dambuwa, North Eastern Nigeria. IOSR Journal of Applied Geology and Geophysics, 1, 20-28. https://doi.org/10.9790/0990-0112028

[18] Onwuemesi, A.G. (1997) One Dimensional Spectral Analysis of Aeromagnetic Anomalies and Curie Depth Isotherm in the Anambra Basin of Nigeria. Journal of Geodinamics, 23, 95-107. https://doi.org/10.1016/S0264-3707(96)00028-2

[19] Stampolidis, A., Kane, I., Tsokas, G.N. and Tsourlo, P.L. (2005) Curie Point Depths of Albania Inferred from Ground Total Field Magnetic Data. Survey in Geophysics, 26, 461-480. https://doi.org/10.1007/s10712-005-7886-2

[20] Salk, M., Pamakeu, O. and Kaftan, I. (2005) Determination of Curie Point Depth and Heat Flow from Magnetic Data of Western Anatolia. Journal of Balkan Geophysical Society, 8, 149-160. 